Caligrama, Belo Horizonte, v. 24, n. 1, p. 89-110, 2019

\title{
Da inesgotável matéria do mundo: uma aproximação pós-humanista à escrita de Maria Gabriela Llansol
}

\section{On the Inexhaustible Matter of the World: A Post-Humanist Approach to the Writing of Maria Gabriela Llansol}

\author{
Ricardo Gil Soeiro \\ Centro de Estudos Comparatistas, Universidade de Lisboa, Lisboa / Portugal \\ ricardogilsoeiro@campus.ul.pt
}

Resumo: O presente artigo centra-se sobre Lisboaleipzig 1: o encontro inesperado do diverso, de Maria Gabriela Llansol, com o objetivo de refletir sobre o enquadramento pós-humanista evidenciado pela escrita de Llansol, procurando argumentar que nesta obra se ensaia uma celebração da interdependência entre o humano e o não humano. Contemplar-se-á, igualmente, uma análise mais ampla da obra de Llansol que, na nossa óptica, incorpora uma ética pós-humanista e encena formas dinâmicas e plurais de subjetividade.

Palavras-chave: Literatura portuguesa contemporânea; Maria Gabriela Llansol; póshumanismo; representações da subjectividade.

Abstract: Our inquiry will focus on Maria Gabriela Llansol's Lisboaleipzig 1: o encontro inesperado do diverso (Lisboaleipzig 1: The Unexpected Encounter with Diversity), aiming at reflecting on the posthumanist framework of Llansol's writing in which it will be claimed that an interdependence between the human and the nonhuman is being enacted. We will also engage in a broader analysis of Llansol's oeuvre, a body of work which, from our perspective, embodies posthumanist ethics and enacts dynamic and plural forms of subjectivity.

Keywords: Contemporary portuguese literature; Maria Gabriela Llansol; posthumanism; representations of subjectivity. 
As palavras vivem de serem vivas, da decisão que as possui, do arrebatamento interior, de não serem bens, propriedades, objectos que se usam e nos desgastam, mas intensidades, sopros onde os corpos se deslocam e se encontram. Amantes. (LOPES, 2013, p. 9)

\section{0 magma da escrita, nos interstícios do mundo}

Enquanto legentes, ${ }^{1}$ movidos pela causa amante que é o Texto, ${ }^{2}$ ler-amar a obra da escritora portuguesa Maria Gabriela Llansol (19312008) significa estar disponível para auscultar uma poética que, no que diz respeito às condições da sua legibilidade e aos propósitos a que se propõe, se situa nos antípodas dos códigos convencionais da dita literatura clássica ou, se quisermos lançar mão de uma outra formulação (igualmente não isenta de complexidades), do realismo expressivo de recorte humanista.

Esta última expressão foi utilizada por Catherine Belsey no seu livro seminal A prática crítica (1992). Aí a autora discorre sobre aquilo que chama "a revolução de Copérnico", querendo sinalizar a transição de um paradigma de unificação centrípeta do Sentido para um descentramento centrífugo dos sentidos, um movimento que vai da unidade para a disseminação, da era da confiança para a era da suspeita, inflingindo-se, então, um rude golpe no narcísico antropocentrismo que havia caracterizado o pensamento ocidental até a irrupção da psicanálise freudiana. Ancorando-se na interpretação que Lacan faz de Freud, o retrato epocal que Belsey nos apresenta é o seguinte:

\footnotetext{
${ }^{1}$ Central no universo mental e ético da escritora, o lexema "legente" (neologismo que atesta a capacidade de M. G. Llansol de se relacionar de forma dúctil com a linguagem, forjando os seus próprios conceitos) aponta para a natureza activa e colaborativa do acto de leitura, um leitor que acolhe o fulgor do texto e que assim se embrenha criativamente no fluxo da escrita.

${ }^{2}$ Referência ao livro homónimo Causa amante, obra que veio a lume em 1984 e que visa sublinhar a dimensão corpórea que atravessa a escrita llansoliana e que pressupõe um profundo envolvimento emocional não apenas por parte do escritor, mas também do leitor.
} 
Lacan chama repetidamente a atenção para a comparação de Freud da sua própria recepção crítica com a recepção concedida à teoria de Copérnico, no século XVI. Freud, defende Lacan, descentrou o ser humano tal como Copérnico descentrara o cosmos; como resultado da obra de Freud, "o próprio centro do ser humano já não pode ser encontrado no lugar que lhe foi atribuido por toda uma tradição humanista" (BELSEY, 1992, p. 133-134).

Mercê desta cesura, aquilo que as palavras de Belsey desafiam é a própria ideologia do humanismo liberal, questionando a época da metafísica da presença (que Derrida visará desconstruir criativamente a partir da filosofia heideggeriana) e esboroando o inamovível centro précoperniciano que enlaçava autor, texto e sentido. Estavam já lançadas as bases teóricas para uma reflexão pós-humanista que viria a caracterizar muito do pensamento dos últimos decénios do século $\mathrm{XX}$.

Nascida deste complexo húmus estético-axiológico em que se verifica uma questionação do sentido do Sentido $^{3}$ (numa formulação que, intencionalmente, pretende fazer lembrar as artes da transcendência propugnadas pela obra de Steiner), a escrita de Llansol move-se, em constante mutação, numa permanente busca em direcção ao inusitado e ao desconhecido; em suma, à singularidade que lateja na tessitura do real: procura sondar o insondável, explorar o ignoto e, assim, mergulha no deslumbramento da ardente indagação sobre o mundo, os seres que o habitam e a linguagem de que estes se servem para poder exprimir a sua condição, simultaneamente trágica e jubilosa, de habitar a terra. Desposando uma liberdade livre da escrita (ecoando um título feliz de António Ramos Rosa), ${ }^{4}$ dir-se-ia que Llansol escreve no limite, para

\footnotetext{
${ }^{3}$ A presente formulação visa sublinhar a inquirição de ordem hermenêutica que caracteriza a reflexão steineriana. Ao longo de um itinerário singular que combina estudos literários, estudos comparatistas e a reflexão filosófica, Steiner advogará uma concepção de sentido onde se revela uma presença real indiciadora de um rasto de transcendência: "Sermos 'habitados' pela música, pela arte, pela literatura, tornaremnos responsáveis por essa habitação, sermos o anfitrião, como o dono da casa o é para um hóspede - talvez desconhecido, talvez inesperado - ao serão, é fazer a experiência do mistério trivial de uma presença real" (STEINER, 2003, p. 48. Grifos do autor).

${ }^{4}$ Uma tal formulação pleonástica pretende justamente atestar a absoluta e indômita radicalidade que singulariza a liberdade da palavra poética. $O$ dom da palavra poética é, assim, perspectivado como um acto em ruptura com o real dogmático, esclerosado e adormecido pelo uso ordinário da palavra comum.
} 
lá da literatura. Exibindo a audácia que quebra as algemas da ordem narrativa (na sua acepção mais chã, convencional e servil), a autora rompe a linearidade discursiva do denominado realismo clássico, forçando as fronteiras do real a expandirem-se, desafiando, assim, os interstícios do pensável e do dizível.

A edificação viva de um original universo literário como este não se traduz num projecto arbitrário: entendê-lo dessa forma seria, creio, falhar o entendimento dos pressupostos em que assenta o traçado do seu programa. Trata-se, ao invés, de um modo mais fiel de estar à altura da in-decifração ontológica do mistério que à empresa humana diz respeito, à estranheza da odisseia da existência, à vertigem que sempre acompanha as perplexidades de que nos alimentamos. Em $O$ senhor de Herbais, que ostenta o sugestivo subtítulo breves ensaios literários sobre a reprodução estética do mundo, e suas tentações, Llansol introduz do seguinte modo a problemática da superação do realismo, procedendo ao elogio de Jorge de Sena:

Sena, para mim, faz parte dos poucos autores do século passado que tentaram ultrapassar "as tentações e os impasses" com que, em todo o Ocidente novelístico e romancista, deparou o realismo. Houve outros - Raul Brandão, Régio, Vergílio, Ruben A., Herberto Helder e o primeiro Almeida Faria (espero não esquecer nenhum, apesar de hesitar sobre Carlos Oliveira). Nenhum deles tentou o surrealismo ou o nouveau roman, que se revelaram tentativas sem consequência. Todos eles se ficaram pelos diversos realismos. Com todos eles aprendi, apesar de serem regressões inevitáveis relativamente a Fernando Pessoa [...]. Pessoa com a sua heteronímia espetou na estética literária realista um dardo praticamente mortal. O que os autores que referi tentaram foi "passar-lhe respeitosamente ao lado" [...] De todos eles, creio que Sena foi o que mais agudamente se deu conta "do molho de bróculos" em que estava metido o realismo. [...] Mas a sua grande obra ficou-nos apenas em títulos e perspectivas. Por escrever, inegavelmente (LLANSOL, 2002, p. 130-131).

A autora confidencia-nos que terá demorado sensivelmente quinze anos até encontrar uma saída viável para o impasse dos diversos realismos (e para a ideia de verossimilhança que estes impunham) com os quais se encontrava em profunda divergência. Augusto Joaquim, marido da autora, afirmou em paratexto dessa obra, que a solução seria encontrada 
no texto orgânico, por oposição ao texto realista, e que convidava a autora a mudar de cultura literária, escolhendo a via de uma alteração profunda da natureza da própria literatura:

Fora encontrado inesperadamente no último quartel do século XX [...] o caminho de outro texto sonhado por Rimbaud, Mallarmé, Joyce, Musil, Rilke, Pessoa e tantos outros. [...] Foise constituindo (para o crítico) um certo consenso em torno das propriedades do texto orgânico. Antes de mais, não obedece ao princípio de verosimilhança mas da fulgurização. Cria figuras e não personagens. A sua temporalidade não se inscreve numa linha de continuidade entre passado-presente-retorno ao passado, mas do futuro (por vezes, muito longínquo) para o presente. (LLANSOL, 2002, p. 160-162)

Não nos deverá surpreender, pois, o modo matizado com o qual a escritora portuguesa se relaciona com a categoria de "literatura", dela se distanciando e chegando mesmo a negá-la hiperbolicamente (negação essa que se confunde, não raras vezes, com uma ironia velada, pois o desiderato seria não abandonar a experiência da escrita propriamente dita, mas sim refutar uma certa concepção normativa de "literatura"). $\mathrm{Na}$ entrada de 2 de Outubro de 1981 do diário O falcão no punho, esclarecese: "Não há literatura. Quando se escreve só importa saber em que real se entra, e se há técnica adequada para abrir caminho a outros" (LLANSOL, 1985, p. 57). Este afastamento voluntário da ideia de uma literatura convencional joga-se, igualmente, na afirmação de uma diferenciação ao nível a) da narrativa e b) do seu conteúdo proposicional. Ao nível da narrativa, estamos perante um texto que se alimenta de "epifanias", "figuras", "nós de intensidade" e de "cenas-fulgor":5

Não escrevo para contar a história de uma personagem exterior a mim a que dou a vida e a morte e nesse intervalo empreende acções, segundo o modelo da escrita representativa. Não faço isso porque não me dá prazer, não me dá força, não me sinto nada testemunha disso, até porque já há tantos escritores que o fazem. De resto o representar esse real parece-me extremamente

\footnotetext{
${ }^{5}$ São várias as formulações de que a escritora se serve para sublinhar o carácter insólito da suas imagens-frases, das suas sentenças poéticas, que concorrem para a intensidade imagética da sua escrita e para uma textualidade possibilitadora do dom poético em detrimento da narratividade clássica.
} 
pueril, infantil no sentido de pouco experiente" (LLANSOL apud GUERREIRO, 2011, p. 33).

Llansol testemunha aqui a insuficiência da escrita representativa e o modo como as suas técnicas operativas lhe são visceralmente estranhas e ontologicamente exteriores. Por outro lado, ao nível do que se pretende transmitir, o conteúdo a tematizar, a tónica é colocada na dicotomia entre escrever sobre (atitude reificante que objectifica assepticamente o ofício da escrita enquanto produto - ergon) e escrever com (atitude existencial que relaciona aquele que escreve com aquilo que é escrito enquanto energeia):

Nunca escreverei sobre nada. Escrever sobre é pegar num acontecimento, num objecto, colocá-lo num lugar exterior a mim; no fundo, isso é escrita representativa, a mais generalizada. Mas há outras maneiras de escrever. Escrever com é dizer: estou com aquilo que estou a escrever. Escrever com implica observar sinais; o meu pensamento é um pensamento emotivo, imagético, vibrante, transformador. É talvez daí que nasce a estranheza desse texto que é um texto imerso em vários extractos de percepção do real (LLANSOL apud GUERREIRO, 2011, p. 33).

A mesma linha de reflexão é retomada numa outra formulação mais apodíctica:

A impostura da língua é pretender que se diz o que não se está a dizer; a pessoa quer dizer o que não está a dizer porque não está a tratar o texto como tal; é querer aproximar-se de outro de quem não se está a aproximar, é querer ter um acesso que não está a ter. A impostura da língua é desviar o texto do seu curso próprio, que é uma intimidade profunda e o que se diz. Para mim, a literatura acabou (LLANSOL apud GUERREIRO, 2011, p. 33).

Como atesta a intransigência do testemunho precedente, aquilo que é repudiado é a falsidade e a alienação de quem não encara a alteridade irredutível do texto, de quem não é capaz de acolher a centelha de singularidade que pulsa em todas as palavras que convocamos. Tudo se passa como se Llansol sentisse na pele a urgência de uma escrita-outra, uma escrita da inquietação, que ao mundo vai ampliando outros mundos alternativos, rasgando inusitados horizontes de sentido. Estamos perante a construção de um espaço edénico que o Texto, em potência, inaugura, 
propiciando um encontro do diverso que fala uma língua sem impostura (para deixar ressoar alguns dos topoi fundamentais da paisagem llansoliana). Um texto, pois, que passa por criar reais-não-existentes, outros mundos possíveis que, numa linguagem wittgensteiniana, se transformariam para o legente noutras tantas formas de vida, isto é, numa genuína possibilidade de realização ética.

Descabida, pois, a acusação de esta ser uma escrita hermética: seria antes uma errância herética, irradiação de múltiplas escutas, uma reflexão feita da linguagem na orla da literatura. Um tal pretenso hermetismo daria, assim, lugar a um erotismo textual que faz apelo a todos os sentidos. Há, quando muito, um excesso de transparência (como sugere, com acuidade, António Guerreiro), um fulgor estético que pressupõe aquilo a que a própria autora classifica de "pacto de inconforto" e que exige ao legente saber ler com o coração.

Na nossa contemporaneidade literária, não vislumbro nenhum outro autor capaz de assumir a radicalidade desta incumbência ética e estética. Pela materialidade do verbo e pela carnalidade da palavra, pelo polifonismo discursivo e pelo derrame de vozes em que se espraia a sua escrita, terá sido Rui Nunes a única excepção no previsível panorama literário português dos últimos decénios. Recusando estanques grelhas romanescas e apostando num projecto verdadeiramente individual, Nunes tem trilhado um caminho muito próprio, exemplarmente traduzido na recente trilogia (A mão do oleiro, 2011; Barro, 2012; Armadilha, 2013) que parece vir a encerrar definitivamente um singular itinerário de pensamento feito escrita. ${ }^{6}$ Consabidamente, uma tal aproximação de Llansol a Nunes nada tem de novo. No ensaio "Rui Nunes: a experiência da desconstrução da linguagem" (incluído no livro Na linha do vento), Maria João Cantinho já ensaiara um sumário cotejo entre ambas as obras, vertido nos seguintes termos:

Tal como Maria Gabriela Llansol, Rui Nunes apenas foi reconhecido tardiamente, pois, em ambos os casos, trata-se de autores de leitura difícil e complexa, avessa aos cânones estabelecidos. Dois casos literários diferentes, mas que partilham a radicalidade da escrita e do trabalho narrativo. Se a escrita de Llansol contém uma raiz mística, e ao mesmo tempo, [...] uma

\footnotetext{
${ }^{6}$ Cf. NUNES, 2011; NUNES, 2012 NUNES, 2013. Veja-se, igualmente, numa linha similar, o mais recente livro do autor, intitulado Nocturno europeu, de 2014.
} 
luminosidade intensa e irradiante, no caso de Rui Nunes há um niilismo e um desespero kierkegaardiano que a atravessa de lésa-lés, deixando-nos a braços com a solidão das suas personagens. (CANTINHO, 2012, p. 62)

A despeito dos universos imagéticos bastante distintos e da irredutibilidade dos respectivos intentos autorais, ambas as obras habitam o mesmo espaço literário de ruptura e de descentramento, participando na supramencionada revolução coperniciana. Cantinho sublinha, com toda a propriedade, que

Para Rui Nunes, é a escrita que verdadeiramente interessa. A escrita como experiência, busca e mergulha em si mesma e no seu universo, não pode falar-se de unidade, ainda que a coerência do texto seja a sua linha decisiva. [...] O autor não se encontra preocupado com a literatura e tão pouco com o acto da escrita em si, despojado, teórico ou reflexivo, se ele não se encontra indissociavelmente ligado aos seres e à sua condição essencial (CANTINHO, 2012, p. 63, grifo meu )

Enquanto em Llansol mergulhamos na exacerbação da energia fulgurante da Palavra, em Nunes somos testemunhas de uma dilaceração da linguagem, num estilhaçar do verbo que mais não é do que um grito trágico "contra o regime totalitário do sentido" (é esse o título da recensão a Barro, da autoria de Maria da Conceição Caleiro, Ípsilon, 2012, p. 28-29). Ambas se desinteressam da unidade narrativa, cultivando um consciente desmembramento da ideia clássica do livro e plasmando-se numa escrita errante e num pensamento nómada. Os textos-fulgurância de Llansol, os textos-irremediáveis de Nunes. Dois lados de um mesmo espelho fracturado. Sobre a ausência de um fio condutor (de índole narrativa) nas suas obras, Nunes reconhece de um modo instigante: "Se calhar não se passa aí [nos meus livros] nada daquilo que as pessoas esperam que se passe; e isso porque é pobre, porque somos confrontados com a nossa mortalidade, com a ausência de Deus. Não conseguem viver com a pobreza que são" (NUNES, 2013, p. 60).

Aqui, escrever contra a literatura (a despeito da literatura; ou, ainda, indiferentemente a ela) não corresponde a um qualquer desejo puramente iconoclasta: aqui, a escrita é, verdadeiramente, encarada como risco e aventura. Com a pena enlaçada ao onírico, Clarice Lispector terá levado ao extremo justamente o sonho de desconstruir a ideia da escrita 
representativa em favor da escrita-improvisação ou da escrita-pintura em que se traduzem muitas das suas obras. Em Água viva (1973), a narradora, que mais não é do que um eu plural em perpétua metamorfose, desafiará a coerência lógica do discurso racional, preconizando a experiência da loucura e da transgressão que brota de uma indômita improvisação da escrita: "Agora vou escrever ao correr da mão: não mexo no que ela escrever. Esse é um modo de não haver defasagem entre o instante e eu: ajo no âmago do próprio instante. [...] Algo está sempre por acontecer. $\mathrm{O}$ imprevisto improvisado e fatal me fascina" (LISPECTOR, 2012, p. 44).

Enquanto ficção inominável e intangível, Água viva é, no contexto da obra lispectoriana, um objecto único, uma espécie de livro por vir. Um anti-livro se quisermos: um objecto facilmente identificável por ser profundamente ilegível no sentido mais radical que é possível atribuir a este termo - como a textualidade infinita de Maria Gabriela Llansol ou as vozes inabarcáveis de Rui Nunes. Todavia, a despeito da inegável "excentricidade" de Água viva, podemos ler em grande parte da obra tardia da escritora brasileira o mesmo desiderato experimentalista e o mesmo ímpeto radical: considere-se, por exemplo, A paixão segundo G. H. (1964), Um sopro de vida (1978) ou até mesmo A hora da estrela (1977).

Em todas estas obras se colocava a questão de saber se ainda estaríamos perante um romance ou se já havíamos atravessado o limiar de uma literatura-outra: a própria autora, numa crónica datada de 14 de fevereiro de 1970 (intitulada "Ficção ou não", incluída no volume $A$ descoberta do mundo), e a propósito de $A$ paixão segundo $G$. H., debate-se com a questão genológica de classificar as suas ficções: "Sei que o romance se faria muito mais romance de concepção clássica se eu o tornasse mais atraente, com a descrição de algumas das coisas que emolduram uma vida, um romance, um personagem etc. Mas exatamente o que não quero é a moldura. Tornar um livro atraente é um truque perfeitamente legítimo. Prefiro, no entanto, escrever com o mínimo de truques" (LISPECTOR, 2013, p. 381).

Escrever com o mínimo de truques, escrever com a carne, escrever fora da literatura. Ou ainda como acautela a própria narradora de Água viva: "Inútil querer me classificar: eu simplesmente escapulo não deixando, gênero não me pega mais" (LISPECTOR, 2012, p. 12). A estudiosa Maria Helena Varela, corroborando esta visão heteróclita da obra de Lispector, argumenta de um modo certeiro: 
Tudo na sua obra [de Lispector] é desfocado, assimétrico, fragmentado, fora do lugar, definindo-se ela própria como 'viceversa e em ziguezague, desacordada e ímpar', culminando a sua escrita intersticial, nunca triunfal, numa autêntica geometria em abismo sem síntese nem redenção. Uma escritura acontecimental, sem teleologias nem reconciliações, a nudez das terceiras margens líquidas, Bodenlos sem causa nem porquê, o entre de todos os devires e vibrações possíveis, de todas as gestações e decomposições. (VARELA, 2003, p. 130)

Uma escrita eminentemente fluida, um frémito de escrita intersticial que visa promover a descontinuidade do pensamento e o atrevimento de uma quase-literatura. Terá sido esse, afinal de contas, o sonho de Llansol: tornar-se corpo audível a um pensamento-outro, tornarse um corpo desejante de escrita, em sentido barthesiano, abdicando da literatura para se entregar, arrebatadoramente, à enigmática vertigem do encontro com a alteridade pela Palavra:

Destituo-me da literatura, e passo para a margem da lingua [...] tão profundamente me sensibilizou o texto que, depois de me ter esquecido o que ia dizer, ou seja, escrever a seguir, me sentei no banco verde do jardim $[. .$.$] a reflectir que me devia perder da$ literatura para contar de que maneira atravessei a língua, desejando salvar-me através dela (LLANSOL, 1985, p. 10).

Haverá mais bela e inesgotável forma de salvação?

\section{Para além-do-humano: vivos no meio do vivo}

É-me impossível dizer eu. Nós, talvez. Mas dizer todos, "com esta que escreve incluída", é melhor. A, aquela, esta, $a$ (LLANSOL, 2010, p. 169, grifos da autora).

Como facilmente se torna observável, ensaiar uma aproximação a um texto de Llansol pressupõe auscultar a totalidade da sua obra como um todo orgânico que a mesma, de facto, configura. Com efeito, ler $O$ encontro inesperado do diverso (obra-charneira na escrita llansoliana a partir da qual pomos à prova a nossa reflexão e para a qual confluem, em última análise, as nossas considerações) exige a rememoração activa de um luminoso labirinto prévio onde a audácia hermenêutica se 
pode fielmente perder, magma de outras vozes e de textos-outros que concorrem, em última análise, para a singularidade do Texto llansoliano. Prosseguiremos à luz desta complexidade, convocando diálogo com essas vozes e com esses textos, tendo em conta a advertência de Llansol quando nos diz que o discurso crítico serve para se escrever sobre os suspiros que rodeiam o texto.

Resultaria, pois, infrutífero desafiar, isoladamente, um só livro de Llansol, amputá-lo do espaço vital onde se integra e em cuja intensidade alcança genuína existência. Se pensarmos em Lisboaleipzig torna-se claro que, pressentido nas páginas de Um falcão no punho, o projecto ganha, de facto, em ser lido à luz dos livros anteriores, constituindo, como defende Pedro Eiras, uma "sinédoque da totalidade da obra" (EIRAS, 2005, p. 544). A primeira parte de Lisboaleipzig 1, por exemplo, constituída por segmentos diarísticos, ${ }^{7}$ estabelece diálogo com a obra anterior, o mesmo sucedendo com a segunda parte, constituída por metatextos teóricos heterogéneos que, em virtude da sua autonomia poetodológica, se libertam do circunstancialismo que os viu nascer.

Poder-se-ia argumentar que cada livro de Llansol constitui o apelo a um novo e sempre eterno recomeço do mundo. Ler Llansol significa recordar esta reinvenção da memória, letras de um alfabeto do deslumbramento que se revisita a si mesmo - exemplo maior de uma poderosa intertextualidade homo e hetero-autoral. O legente depara e dialoga com essas personagens em trânsito, reconhece recorrências

${ }^{7}$ É inegável que a dimensão diarística é central para a escrita llansoliana, mesmo quando os seus textos não são formalmente catalogados em diários. Essa centralidade encontra-se bem patente na seguinte confidência: "consigo escrever apenas em Diário" (LLANSOL, 1985, p. 62). Os livros que se apresentam explicitamente enquanto diários dividem-se em dois trípticos, um primeiro painel constituído por Um falcão no punho (1985), Finita (1987) e Inquérito às quatro confidências (1997); e um segundo painel que veio a lume recentemente, o projecto "Livro de horas", constituído por Uma data em cada mão, v. 1. Lisboa: Assírio e Alvim, 2009; Um Arco Singular, v. 2. Lisboa: Assírio e Alvim, 2010; Numerosas linhas, v. 3. Lisboa: Assírio \& Alvim, 2013. Vejase a seguinte passagem: "a primeira imagem do Diário não é, para mim, o repouso na vida cotidiana, mas uma constelação de imagens, caminhando todas as constelações umas sobre as outras [...] Eu diria: aqui está a raiz de qualquer livro" (LLANSOL, 2009 , p. 19). Veja-se também a noção de diário-enquanto-signografia explicitada em Inquérito às quatro confidências. Sobre a escrita diarística de Llansol, cf. VAZ, 2005, SOARES, 1998, p. 50-58. 
topológicas e vislumbra itinerâncias temáticas que se desdobram em múltiplos sentidos. Nesta complexa cartografia afirma-se a celebração da textualidade, em detrimento da peripécia e de um universo de referentes facilmente identificáveis. Uma "comunidade sem pressupostos e sem sujeitos" - é assim, em clave agambiana, que Pedro Eiras (2008) caracteriza, por exemplo, Os cantores de leitura (2007). O fundamento deixa de ser magma primordial, sendo que a escrita seduz e a mão guia - será esse o ditame que o corpo escolhe aceitar: "Escrevi o que escrevi, porque a escrita me mandou escrever, e eu obedeço, com um princípio de confusão na mente" (LLANSOL, 2007, p. 103, grifos da autora).

A presença de várias figuras europeias no Texto llansoliano deve ser perspectivada à luz da revisão da história e da concomitante construção do humano que a sua obra reclama - o projecto trans-histórico que podemos surpreender na primeira trilogia do princípio dos anos 1970:

Há muitos anos, quando comecei a viver na Bélgica, sem pressentir que seria por tantos, esta nossa longa ausência fez-me uma profunda impressão. Estava eu no béguinage de Bruges, com o sentimento fortíssimo de que já ali teríamos estado. Nós, não era eu. Já ali tínhamos sido alguém, alguém daquele lugar, e agora, inexplicavelmente, não havia ali, excepto na minha impressão, nenhuma memória de nós. Nem sequer o esquecimento. Data de então a presença constante, invasora e quase exclusiva, de certas figuras europeias nos meus livros [...]. Fez-se ali o nó de que depois desfiei o texto. Comecei nas beguinas; destas, passei a Hadewijch, a Ruysbroeck. Destes, a João da Cruz e a Ana de Peñalosa. Fui conduzida por todos eles a Müntzer, à batalha de Frankenhausen e à vidade utópica de Münster, na Vestefália. Nos restos fracassados destes homens encontrei Eckhart, Suso, Espinosa, Camões e Isabel de Portugal. E foi por sua mão que fui até Copérnico, Giordano Bruno, Hölderlin, que todos eles anunciavam Bach, Nietzsche, Pessoa, e outros que a nossa memória ora esquece, ora lembra tão intensamente que me parece outra forma de os esquecer. De esquecer tudo isso (LLANSOL, 1994a, p. 88-89).

A edificação de uma contra-visão da história da Europa dará lugar a uma reformulação do projecto humano para além da história: uma ontologia a-histórica que celebra um "contrato com o Vivo" e que abraça uma visão "estética" do mundo. Sobre este projecto se debruçou João Barrento com a habitual acuidade crítica: 
O seu texto não sonha já sonhos impossíveis de liberdade política, a "comunidade" alarga-se e transforma-se, sem deixar para trás a sua configuração "demo"-crática particular (a do "povo" dos pobres da história), mas abrindo-se a uma bio-cracia, qualquer coisa como uma aisthesis universalis sob o signo, não do tempo da história e das suas Figuras (porque "chegou o momento de sair da História e ir viver no mundo de seiscentos milhões de anos", [...]), mas do "Há" e de uma "restante vida" transposta para o plano total, cósmico, do Ser (entendo aqui a categoria do "Há", que Llansol terá pedido de empréstimo a Levinas, como um espaço onde tudo converge e tudo se confunde, um líquido amniótico do Ser, aquele fundo, histórico e ontológico, sobre o qual se inscreve cada Figura e todo o Vivo). (BARRENTO, 2011, p. 17)

Para Barrento, o facto de estarmos perante a construção de um universo trans-histórico textualizado não significa que do horizonte llansoliano esteja ausente uma aguda dimensão política e ética. Pelo contrário, nele se inscreve, com fecundo fulgor, um movimento que nos leva do tempo da história ao espaço do texto: desenha-se, assim, um lugar para aquilo a que Llansol chama, em Finita (2005), o "eterno retorno do mútuo". Ecoando o célebre tema nietzschiano do eterno retorno do mesmo (Die ewige Wiederkunft des Gleichen), uma tal formulação, que é recuperada em $O$ encontro inesperado do diverso, remete para a possibilidade de uma restante vida (contra a violência dos poderes). ${ }^{8}$ Poder-se-ia argumentar que Llansol propõe um novo humanismo, uma espécie de pós-humanismo crítico: Barrento (2011, p. 21) falará em "humanismo de risco", uma espécie de renovada "visão do humano".

Em que moldes, se poderá entender um tal pós humanismo? Poderíamos começar por dizer que toda a sua Obra se deixa seduzir pelo desafio ontológico de superar os constrangimentos antropocêntricos em que, afinal, sempre terá repousado a metafísica ocidental. Os seus textos questionam hierarquias, interrogam dicotomias, contestam

\footnotetext{
${ }^{8}$ Trata-se dos sobreviventes da história, os pobres que assomam em $A$ restante vida (1983), o segundo livro da primeira triologia, intitulada "Geografia dos rebeldes" e que inclui também O livro das comunidades (1977), e Na casa de julho e agosto (1984). A segunda trilogia, intitulada "O litoral do mundo", inclui Causa amante (1984), Cantos do mal errante (1986) e Da sebe ao ser (1988).
} 
antagonismos. ${ }^{9}$ Tendo como referente a dinâmica do ser, a vibração do Vivo e a presença de mundos no mundo, o Texto llansoliano está povoado por múltiplas figurações do não humano e do híbrido: jamais ousa apossar-se de uma definição do que constitui o humano, preferindo falar em singulares, seres únicos na semelhança do mútuo. Essa resistência a uma tal cristalização essencialista está patente no seguinte passo de O senhor de Herbais: "O humano é indefinível, quem quiser que tente, e verá como dizer 'eis o humano' é dizê-lo pela boca do tirano, [...]" (LLANSOL, 2002, p. 274).

Consideremos, igualmente, a obra Amar um cão: amor ímpar para fora de si em direcção a um ser-outro, o cão Jade, que nasce, vive e morre (a despossessão de si, na formulação incontornável de Silvina Rodrigues Lopes). Já em O encontro inesperado do diverso, a dualidade hierárquica de que se alimenta o pensamento antropocêntrico é posta em questão de uma forma lapidar: "enquanto dualidade pensada e assumida, tem causado imensas e incalculáveis perdas ao ser humano mais comum. A ele, mas também a esta pedra, a este arbusto, a este bicho" (LLANSOL, 1994a, p. 99).

O mundo-tarefa a que o Texto llansoliano aspira celebra-se na convivência justa, num "contrato de mútua não anulação" entre todos os seres, entre os outros-diferentes-entre-si. Abrindo-o a todo o "Vivo", Llansol desloca, assim, o conceito de "humano", propondo a sua emigração para aquele locus/logos, paisagem onde não há poder sobre os corpos" (LLANSOL, 1994a, p. 121). Vejamos a seguinte passagem de Parasceve: "No preciso momento em que um vivo entra em contacto com uma pessoa, isso torna-se vivo, e começa o pensamento. Vivo não é, pois, bio nem matéria. Não é carne nem espírito. Não é mecânico nem vital. Não é unidade nem múltiplo. É uma relação entre pessoas, seja qual for a sua ordem, em busca de uma arte de viver, ou seja, de mútua não anulação" (LLANSOL, 2001b, p. 61).

$\mathrm{O}$ modo como Llansol chama a atenção para os limites do $\mathrm{Eu}$ antropocêntrico é desarmante para a própria subjectividade, redutora

\footnotetext{
${ }^{9}$ Esta temática parece-nos ainda pouco explorada pela exegese llansoliana. Ainda assim, importa mencionar o estudo seminal de Maria Etelvina Santos, intitulado "Onde a Natureza é Mais-Paisagem há um Corpo que Escreve". In: Vivos no meio do vivo. $3^{\circ}$ Colóquio International de Maria Gabriela Llansol. Lisboa: Espaço Llansol, 2007, p. $60-72$.
} 
quando vista por um prisma puramente humano: "um eu é pouco para o que está em causa", lemos em Onde vais, drama-poesia? (2000, p. 182). $\mathrm{O}$ eu humano é encarado enquanto parte de um todo mais amplo, sendo a ipseidade concebida como a caixa de ressonância de uma absoluta alteridade: "fazer de nós vivos no meio do vivo" (LLANSOL, 1994a, p. 120, grifo do autor).

No seminal ensaio "Ensinar poesia no século XXI: a (im)possível resposta a um desejo infinito. Do comparativismo à 'hospitalidade' de Maria Gabriela Llansol" (2011), Paula Mendes Coelho aborda justamente a noção de hospitalidade, procurando equacionar a literatura no século XXI, no contexto da crise da relação da sociedade com as humanidades, sublinhando, com indiscutível propriedade, a centralidade do papel da leitura. Llansol é aqui lida à luz do conceito de hospitalidade propugnado por Derrida (embora este ângulo de análise seja lacunarmente enunciado e me pareça carecer de um tratamento mais profundo). Seguindo na pista derridiana, diríamos que Llansol celebra a experiência de uma radical alteridade: acolhe vozes, numa abertura fértil ao Outro - à estranheza inquietante que a singularidade do totalmente Outro sempre é. Como continuar o humano? - pergunta o texto llansoliano (LLANSOL, 1994a, p. 20).

$\mathrm{O}$ dom poético, conducente à liberdade de consciência, aponta para uma vibração existencial em cujo seio pulsa a imaginação criadora. A intensidade das múltiplas cenas-fulgor, despedindo-se do paradigma realista da narratividade, convoca uma textualidade perpetuum mobile, um inacabamento perpétuo nas palavras justas de Francis Ponge. 10 "Onde vais drama-poesia?" - tal é a pergunta enquanto princípio irradiante que ressoará sempre na obra de Llansol, na experiência radical de linguagem e de projecto ético-ontológico que ela corporiza. Se "o texto não consola" (LLANSOL, 1999, p. 126), lemos em Ardente texto Joshua, é porque o texto é "sem promessa e sem garantia" (LLANSOL, 2000, p. 188). Quanto à problemática do horizonte de um novo humanismo, Llansol responderá, na obra $\mathrm{Na}$ casa de julho e agosto: geografia de rebeldes III, em termos quase axiomáticos, numa espécie de messianismo sem messianismo: "O homem será" (LLANSOL, 2003c, p. 166). ${ }^{11}$

\footnotetext{
${ }^{10}$ Cf. PONGE, 1984.

${ }^{11}$ A questão complexa do messianismo em Llansol permanece, a meu ver, incipientemente trabalhada. Cantinho (2004) alude a esse sopro messiânico, mas trata-se, efectivamente, de uma problemática que carece de um maior aprofundamento.
} 
Em Uma razão dialógica: ensaios sobre literatura, a sua experiência do humano e a sua teoria, Manuel Gusmão dedica dois capítulos à obra de Llansol: "A história e o projecto do humano" (GUSMÃO, p. 195-218) e "O amor ímpar ou o terceiro incluído" (GUSMÃO, p. 219-228). Numa leitura minuciosa, Gusmão intima o legente a reaprender a linguagem que relaciona com a própria " $r e-$ invenção de possíveis" (GUSMÃO, 2011, p. 196). O poeta e crítico atenta no efeito do texto, sublinhando a partir da negação da transparência da escrita llansoliana o modo como a dialéctica do invisível e do visível constitui uma das veredas como na sua escrita se funda uma responsabilidade perante o Vivo. Uma rede textual complexa em que se semeiam múltiplas referências, podendo ser considerado um palimpsesto feito de fios incontáveis. Em O livro das comunidades, lemos:

Leio um texto e vou-o cobrindo com o meu próprio texto que esboço no alto da página mas que projecta a sua sombra escrita sobre toda a mancha do livro. Esta sobreposição textual tem por fonte os olhos, parece-me que um fino pano flutua entre os olhos e a mão e acaba cobrindo como uma rede, uma nuvem, o já escrito. (LLANSOL, 1977, p. 65)

O aspecto para o qual Gusmão, com acutilância, chama a nossa atenção é para uma reconfiguração poiética do humano:

É que o projecto do humano enquanto aberto passa pelo reconhecimento de que a vida "não é essencialmente nem principalmente humana" e daí decorre um desejo de que o humano reconheça em si ou se abra e dê palavra ao que nele não é humano. [...] Receber do não-humano novas harmónicas do humano implica ainda reconhecer não apenas que ele não é todo o vivo mas que há um estado de deficiência do humano (GUSMÃO, 2011, p. 216-217, grifo do autor).

Somos, pois, confrontados com uma radical poética do encontro, uma poética que à pergunta de escravo "Quem sou eu?" faz sobrepor a pergunta de um homem livre: "Quem me chama?". Hospitalidade face a outras vozes, a outras alteridades e a outros-clamores totalmente Outros. Esta centralidade da ética em Llansol encontra-se plenamente actuante em $O$ encontro inesperado do diverso: "Alguém, desde o princípio, está sentado à nossa porta, pedindo abrigo, partilha de pão, reciprocidade" 
(LLANSOL, 1994a, p. 145). A exigência do apelo e da relação plasma-se no primado da ética, aproximando-se claramente da crítica brochiana da arte pela arte: "convencida intimamente de que o belo tinha de ser salvo de qualquer embelezamento, para lá de toda a estética, e firmemente empenhado no corpo e no afecto" (LLANSOL, 1944a, p. 145-146).

O mesmo sucede ao nível da recusa da hierarquização dos entes, como no seguinte testemunho de cariz autobibliográfico:

Há leitores que sempre se admiraram com a presença nos meus textos, de animais e de plantas, ao mesmo nível ontológico do ser humano. Mas não há que admirar porque elas são formas da mesma imagem e excelentes mestres do ser humano no estabelecimento das relações deste com a Presença não humana (LLANSOL, 1944a, p. 141).

É justamente essa não hierarquização radical das formas vivas que me parece fundamental para um entendimento do horizonte pós-humanista em que se inscreve o labor llansoliano e que concita a nossa atenção para a proximidade entre as formas vivas e para uma comunidade profunda, um "espaço-nó" e de "semente". Na página 143 de Lisboaleipiz 1, a autora chega a tecer algumas considerações em torno de Finita, reportando-se ao conceito de "eterno retorno do mútuo" (a que já nos reportamos) que define como sendo "a boa-nova da criação anunciada a todo o vivente" (LLANSOL, 1994a, p. 143). Subjacente a esta boa-nova está, sem dúvida, a questionação do "exclusivismo humano" que Onde vais, drama-poesia? (p. 207) encetara e que também assoma meridianamente em Finita: "Quando é que o homem, de forma mais capaz, se julgou forma única e exclusiva?" (LLANSOL, 2005, p. 124-125).

Pergunta João Barrento no ensaio "A voz dos tempos e o silêncio do tempo", incluído em Na dobra do mundo: "faz sentido perguntar pelo sentido da história e pelos fins do homem na Obra de Maria Gabriela Llansol? Significa isso reconhecer que o seu projecto transporta ainda consigo a crença numa qualquer forma de humanismo?" (BARRENTO, 2008, p. 155). A resposta negativa, que concita o nosso assentimento, não podia ser mais esclarecedora a este respeito:

a haver aqui um "humanismo", ele não corresponde a nenhuma crença apriorística numa essência do homem ou do humano, mas antes a uma esperança no vivo, no que é singular, no que está a acontecer e em devir ("Nada foi, tudo está sendo"). 
Nenhuma "ideia" do homem ilumina a Comunidade. [...] Não há aí lugar para $o$ Homem. [...] $o$ Homem não é figura desta Obra (pela simples razão de que $o$ Homem não pode ser figura). Nem o "humano" é aí um datur (um a priori que é dado), mas antes um tertium non datur, o terceiro excluído da história (a casa da Comunidade é "casa dos pobres da história"), entre a barbárie obscurantista e as luzes da razão, um objecto do desejo. (BARRENTO, 2008, p. 155-156, grifo do autor).

Estamos, com efeito, perante uma obra que faz estremecer essencialismos e a própria ideia de identidade-cristalização parece estar subordinada ao dinâmico princípio da metamorfose-devir: "Aidentidade é precária. Por vezes, serve. Outras vezes, não", lemos em Parasceve (LLANSOL, 2001b, p. 100).

Indesmentível, pois, a dimensão ética do projecto llansoliano que se plasma na recusa do solipsismo, na disponibilidade para a metamorfose e no apelo da intersubjectividade. Emerge, assim, uma cosmovisão que contempla as figuras do rebelde, do eremita e do pobre por oposição ao Príncipe enquanto figura do poder. Parece-nos que o quadro éticofilosófico de uma hermenêutica radical (no sentido de uma fenomenologia da justiça propugnada por John Caputo, ancorada em Derrida e em Lévinas - como um modo de expor o mito do Ser ao choque do mito greco-judeu da justiça), nos permite dar conta, satisfatoriamente, da complexidade e da exigência que o pensamento de Llansol coloca ao seu legente. Formulada, já, por diversas vezes, ${ }^{12}$ a aproximação da escrita llansoliana à filosofia do Rosto, preconizada por Lévinas, é descrita nos seguintes termos por Pedro Eiras em Esquecer Fausto:

A proximidade do pensamento de Lévinas é sensível na ideia do texto como espaço de hospitalidade (Aossê acolhido na família Bach, Prunus Triloba pelo "espaço Llansol” em Jodoigne, textos colhidos por Lisboaleipzig); na formação da subjectividade pela intersubjectividade da "dádiva", recusando-se o solipsismo [...]. Os limites do sujeito não são definidos por contraposição com os do outro mas no acolhimento do Rosto do outro. Na metáfora

\footnotetext{
${ }^{12} \mathrm{Cf}$. BARRENTO, 2012, particularmente a esclarecedora nota de rodapé n. 4. Numa linha oposta, para uma distinção entre o "Há" llansoliano e o "Há" lévinasiano (aquilo que, em Le Temps et l'autre, 1979, designou por "irremissível existir puro"), cf. NUNES, 2008, p. 15-35.
} 
lévinasiana, o Rosto pede ao sujeito um laço de respeito religioso; em Maria Gabriela Llansol, o rosto é lugar de revelação (EIRAS, 2005, p. 610).

Secundamos, obviamente, as argutas palavras do autor de $U m$ certo pudor tardio. Mas não podemos deixar de assinalar que, na nossa óptica, o factor absolutamente decisivo é o modo como o Texto llansoliano logra suplantar a estreiteza da ética lévinasiana, firmando, assim, irreversivelmente a radicalidade do seu projecto ético. O Outro, em Lévinas, jamais ostenta um rosto não humano. Já em Llansol, o humano está em permanente interacção com os demais entes, diferentes possibilidades de ser-no-mundo. Numa ficção nómada como esta, escritamundo que recusa o enclausuramento e alberga o inacabamento, não nos deve admirar que se declare em $O$ senhor de Herbais: "O Alguém por que chama a estética que cultivo é humano e não humano. É simplesmente a consciência do vivo, seja qual for a forma como se apresenta à retina o Olho Primitivo" (2002, p. 104). E, ainda nessa obra, numa passagem que constitui um inolvidável testemunho do que significa ser-se humano, proclama-se com lúcida humildade: "O meu corpo é a minha paisagem terreste, cuja nascente é a matéria estelar. Vindo de tão longe e de tão imenso, como se poderia contentar com a mediocridade gregária, reduzida ao mero humano e à nesga de visível que é a duração de uma vida" (LLANSOL, 2002, p. 210).

Convidando-nos a equacionar uma ética para-além-do-humano, a obra llansoliana abraça uma englobante perspectiva cósmica que, desconstruindo quaisquer pretensões antropocêntricas, abarca a "Presença não humana" (LLANSOL, 1994a, p. 141), inscrevendo-a no horizonte de uma radical des-hierarquização dos seres. Celebrando metamorfoses inusitadas e encontros inesperados do diverso, fala-nos do sentido em perpétuo movimento e do júbilo que é achar-se vivo no meio dos vivos.

\section{Referências}

BARRENTO, J. (org.). Europa em sobreimpressão: Llansol e as dobras da história. Lisboa: Assírio \& Alvim, Espaço Llansol, 2011.

BARRENTO, J. Identidade e Literatura: o Eu, o Outro, o Há. Diacrítica, [S.l.], v. 3, n. 26, p. 9-40, 2012. 
BARRENTO, J. Na dobra do mundo: escritos llansolianos. Lisboa: Mariposa Azual, 2008.

BELSEY, C. A prática crítica. Lisboa: Edições 70, 1992.

CANTINHO, M. J. Na linha do vento: ensaios escolhidos. Lisboa: Tertúlia de e-books, 2012.

CANTINHO, M. J. Tempo e imagem na obra de Maria Gabriela Llansol. Revista Faces de Eva, Lisboa, v. 11, p. 25-40, 2004.

COELHO, P. M. Ensinar poesia no século XXI: a (im)possível resposta a um desejo infinito. Do Comparativismo à 'Hospitalidade' de Maria Gabriela Llansol. In: SILVA, J. A. C.; MARTINS, J. C. de O. (org.). Pensar a literatura no século XXI. Braga: Publicações da Faculdade de Filosofia, Universidade Católica Portuguesa, 2011. p. 287-305.

EIRAS, P. Esquecer Fausto: a fragmentação do sujeito em Raul Brandão, Fernando Pessoa, Herberto Helder e Maria Gabriela Llansol. Porto: Campo das Letras, 2005.

GUERREIRO, A. Na margem da língua, fora da literatura. In:

Caderno de leituras. Lisboa: Mariposa Azual, 2011, p. 33.

GUSMÃO, M. A história e o projecto do humano. In: . Uma razão dialógica: ensaios sobre literatura, a sua experiência do humano e a sua teoria. Lisboa: Edições Avante, 2011, p. 195-218.

GUSMÃO, M. O amor ímpar ou o terceiro incluído. In: .Uma razão dialógica: ensaios sobre literatura, a sua experiência do humano e a sua teoria. Lisboa: Edições Avante, 2011, p. 219-228.

LISPECTOR, C. A descoberta do mundo: crónicas. Lisboa: Relógio D’Água, 2013.

LISPECTOR, C. Água viva. Lisboa: Relógio D’Água, 2012.

LLANSOL, M. G. Ardente texto Joshua. Lisboa: Relógio D’Água, 1999. LLANSOL, M. G. Causa amante. 2. ed. Lisboa: Relógio D’Água, 1996. LLANSOL, M. G. Finita: diário 2. 2. ed. Lisboa: Relógio D’Água, 2005. LLANSOL, M. G. Lisboaleipzig 1: o encontro inesperado do diverso. Lisboa: Rolim, 1994. 
LLANSOL, M. G. Na casa de julho e agosto. 2. ed. Lisboa: Relógio D’Água, 2003c.

LLANSOL, M. G. O livro das comunidades. Lisboa: Relógio D’Água, 1977.

LLANSOL, M. G. O senhor de Herbais: breves ensaios literários sobre a representação estética do mundo e suas tentações. Lisboa: Relógio D’Água, 2002.

LLANSOL, M. G. Onde vais, drama-poesia? Lisboa: Relógio D’Água, 2000.

LLANSOL, M. G. Os cantores de leitura. Lisboa: Assírio \& Alvim, 2007.

LLANSOL, M. G. Parasceve: puzzles e ironias. Lisboa: Relógio D’Água, $2001 b$.

LLANSOL, M. G. Um falcão no punho: diário 1. Lisboa: Edições Rolim, 1985.

LLANSOL, M. G. Uma data em cada mão: livro de horas I. Lisboa: Assírio \& Alvim, 2009.

LOPES, S. R. Teoria da despossessão: sobre textos de Maria Gabriela Llansol. Lisboa: Edições Averno, 2013.

NUNES, M. A. Como uma pedra-pássaro que voa. Lisboa: Mariposa Azual. 2008.

NUNES, R. A mão do oleiro. Lisboa: Relógio D’Água, 2011; Barro. Lisboa: Relógio D'Água, 2012

NUNES, R. Armadilha. Lisboa: Relógio D’Água, 2013.

NUNES, R. Barro. Lisboa: Relógio D’Água, 2012.

NUNES, R. Nocturno europeu. Lisboa: Relógio D’Água, 2014.

NUNES, R. Uma plenitude terrível. Maria da Conceição Caleiro entrevista Rui Nunes. Cão Celeste, Lisboa, n. 4, p. 60, 2013.

PONGE, F. Pratiques d'écriture ou l'inachèvement perpétuel. Paris: Hermann, 1984 
SOARES, M. de L. O diário de Llansol: a ordem figural do cotidiano. In: ANDRADE, P. de; SÉRGIO A. (ed.). Um corp'a 'screver 2. Belo Horizonte: FALE/UFMG, 1998. p. 50-58.

STEINER, G. Paixão intacta. Lisboa: Relógio D’Água, 2003.

VARELA, M. H. Clarice Lispector: da metafenomenologia dos prazeres a uma ontologia do neutro. Ex Aequo, [S. l.], n. 9, p. 130, 2003.

VAZ, C. Diários de um real-não-existente: ensaio sobre os diários de Maria Gabriela Llansol. Lisboa: Labirinto, 2005.

Recebido em: 12 de março de 2018. Aprovado em: 19 de setembro de 2018. 